\title{
Molecular Identification of Pathogenic Bacteria in Kantong Semar Plants (Nepenthes Gracillis) Based on Mitochondrial 16S rRNA Gene
}

\author{
Rahmad Agus Prasetio, Isnawati ${ }^{*}$, Dwi A. Rahayu \\ Biology Department, Universitas Negeri Surabaya
}

\begin{abstract}
Nepenthes is a protected and unique carnivorous plant because it has a fluid-filled pouch at the end of the leaf that serves as an insect trap. The existence of Nepenthes gracillis in ecosystems is endangered, one of the reasons is caused by the attack of pathogenic bacteria, so it is necessary to identify pathogenic bacteria that attack $N$. gracillis as an effort to handle. The purpose of this study was to identify pathogenic bacteria in $N$. gracillis using $16 \mathrm{~S}$ rRNA gene sequencing results. This study aims to identify the $16 \mathrm{~S}$ rRNA sequence and phylogenetic of bacteria attached in $N$. Gracillis leaves, and the identification was confirmed using molecular data. The construction of phylogenetic topology was made based on ML and NJ method using Kimura-2 parameter model. Subsequently, molecular characterization and identification was conducted based on $720 \mathrm{bp}$ of $16 \mathrm{~S}$ rRNA gene similarity, sequence variation, genetic distance, and phylogenetic topology. According to the results, the bacteria species attached in N. Gracillis identified as Lelliottia nimipressuralis, and closely related with Erwinia aphidicola. Genetic distance between sample and related species was 0,0173 , with $98,26 \%$ similarities, then strongly 100 bootstrap analyses. Thus, this study provides more information for Lelliottia nimipressuralis phylogenetic studies using different marker.
\end{abstract}

Keywords: Nepenthes gracilis, Pathogenic bacteria, Mitochondrial gene

\section{Introduction}

Nepenthes (locally known as monkey cup) is a tropical carnivorous plant that has evolved modified leaves as external digestive organs via the leaf epiascidiation process in order to acquire nutrients from prey trapped within pitcher cups [1]. Nepenthes is a monotypic family Nepenthaceae, also known as tropical pitcher plants or monkey cups. Nepenthes is the only genus in the Nepenthaceae tribe that is classified as a carnivorous plant, as it survives in low-nitrogen environments by eating insects and small animals [2]. Nepenthes can thrive in soils with high acidity and very low levels of essential nutrients such as nitrogen, phosphorus, and potassium, in which other plants struggle [3].

The presence of Nepenthes in nature plays an important role in the functioning of an ecosystem. Nepenthes is useful as an insect biological control agent because it provides nectar to insects[3]. Nepenthes has a symbiotic relationship with chitinolytic bacteria found in Nepenthes cotton fluid, and these bacteria can be used as potential and environmentally friendly biological controllers to deal with pests and pathogens, particularly insects, in cultivated plants [4].

\footnotetext{
* Corresponding author : isnawati@unesa.ac.id
}

Pathogenic bacteria are also one of the factors that cause a decrease in the number of Nepenthes in their habitat because it can cause death in Nepenthes, such as research conducted by Fanani [5], which has identified phenotypically pathogenic bacteria that cause disease in Nepenthes mirabilis, Nepenthes ampularia, Nepenthes rafflesciana, Nepenthes ampularia and Nepenthes rafflessiana with conventional methods. The results showed that the cause of Nepenthes disease caused by pathogenic bacteria from the genus Erwinia causing wet brown spots on the leaves of $N$. mirabilis.

The 16S rRNA gene sequence is a molecular marker that is widely used in the identification, phylogenetic, and classification of bacteria because it has identical ubiquity and function in all bacteria [6]. 16S rRNA sequences can also be used to determine conserved traits that are passed down from generation to generation. Barus [7] suggested that the 16S rRNA gene sequence is universal, exists in all bacteria, and is highly conserved. The 16S rRNA gene region can be used to identify unknown bacteria, and can analyze phylogenetic relationships with relatively distant taxa.

Based on our previous research showed that pathogenic bacteria attached in Nepenthes was Lelliottia nimipressuralis based on high similarity on BLAST online. However, further bioinformatics analysis is 
required to determine the type of pathogenic bacteria. This study aims to identify the 16S rRNA sequence and phylogenetic of bacteria attached in N. Gracillis leaves, and the identification was confirmed using molecular data.

\section{Materials and Methods}

\subsection{Time and Location of Research}

The study was carried out from October 2020 to January 2021. Samples were taken from Bromo Tengger Semeru National Park, which can familiar as Nepenthes gracillis. Bacterial isolation and culture were carried out at the Microbiology Laboratory of Building C9, Universitas Negeri Surabaya, while molecular analysis was carried out at the Laboratory of Molecular Biology, Department of Biology, Faculty of Science and Technology UIN Maulana Malik Ibrahim Malang, than the sequencing was carried out using the sequencing services of First Base Laboratories Sdn Bhd.

\subsection{Material and Equipment}

The materials used in this study included Nutrient Agar (NA) and Nutrient Both (NB) media for bacterial growth, 5.3\% sodium hypochlorite, sterile distilled water, 70\% alcohol, 96\% alcohol, crystal violet, lugol, and safranin, DNA isolation kit, GT1 buffer, GT2 buffer, W2 buffer, elution buffer, agarose gel, 1x TAE buffer, loading dye, ethidium bromide (EtBr), proteinase $\mathrm{K}$, universal $16 \mathrm{~S}$ primer.

The equipment was used petri dishes, pestle, mortar, spirtus lamp, vortex, plastic warp, analytical balance, dropper pipette, beaker glass, incubator, LAF, spatula, object glass, cover glass, ose, micropipette, erlenmeyer, hotplate, aluminum foil, apendorf tube, test tube, PCR Biorad, UV transilluminator, autoclave, and gloves.

\subsection{Bacterial Isolation}

The bacterial isolation process was carried out by taking samples from Nepenthes which showed symptoms of disease caused by pathogenic bacteria with morphological symptoms of red nodules and spots spreading on the surface of the leaves, stems, and pockets of Nepenthes, and could cause Nepenthes tissue to die (Picture 1.) based on our previous research. This characters according to research conducted Fanani (2015). Isolation of bacteria was carried out based on the method used by Safira (2014), parts of Nepenthes leave those experienced symptoms of disease in a fresh state were washed thoroughly with running water then cut 1 $3 \mathrm{~cm}$ long, pieces of leaves were soaked in $70 \%$ alcohol for 1 minute, hypochlorite solution $5.25 \%$ for 5 minutes, then soaked in $70 \%$ alcohol for 1 minute, the sample was then rinsed with sterile distilled water three times, then dried with sterile filter paper. The sterilized leaves were crushed with mortar and pestle, the sample was added with $10 \mathrm{ml}$ of sterile distilled water, then diluted up to 10-7.

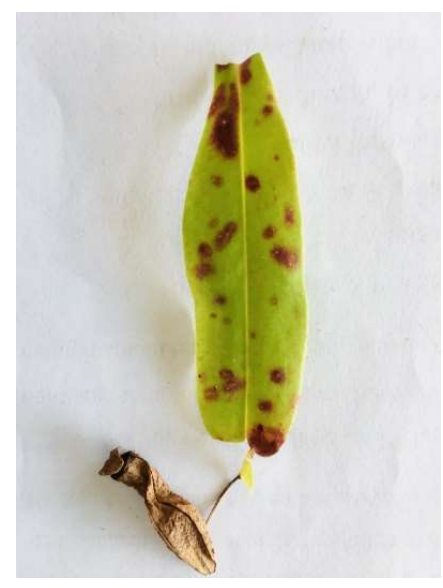

Fig 1. Nepenthes gracillis leaves infected with pathogenic bacteria

\subsubsection{DNA Isolation}

Molecular analysis was carried out at the Laboratory of Molecular Biology at the State Islamic University of Maulana Malik Ibrahim, Malang, Indonesia. The isolation stage of bacterial DNA was carried out by taking $1.5 \mathrm{ml}$ of bacteria on NB media and transferred to a tube, then adding $180 \mu \mathrm{L}$ of GT1 buffer and then vertexing, adding $200 \mu \mathrm{L}$ of GT2 buffer and proteinase $\mathrm{K}$ then vortexing, then incubation at $56^{\circ} \mathrm{C}$ for 10 minutes, during incubation the tube was turned back and forth every 5 minutes, added $200 \mu \mathrm{L}$ of absolute ethanol and then briefly vortexed, the sample was inserted into the Spin Column and then centrifuged at 13,000 rpm for 1 minute, discarded flow-through and added 5001 buffer W1 in the Spin Column was then centrifuged at 13,000 rpm for 1 minute, the flow-through was discarded and centrifuged again for 2 minutes at 13,000 rpm. The DNA in the Spin Column was transferred to a new $1.5 \mathrm{ml}$ tube, then added 50-100 1 of elution buffer and incubated at room temperature for 1 minute, then centrifuged for 1 minute at a speed of $13,000 \mathrm{rpm}$, the DNA was purified for the next step, the purified DNA was stored at temperature of $-20 \mathrm{oC}$ for short-term storage, and at $70^{\circ} \mathrm{C}$ for long-term storage. The results of DNA isolation were measured using a UV NANO DROP 2000 spectrophotometer.

\subsubsection{Amplification}

The amplification step used a specific primer for the universal 16S rRNA gene amplification 1492R 5'TACGGYTACCTTGTTACGACTT-3', 27F 5'AGAGTTTGATCMTGGCTCAG-3', the amplification was carried out in 40 cycles, the initial stage of amplification was pre-denaturation at $95^{\circ} \mathrm{C}$ for 2 minutes, denaturation at $95^{\circ} \mathrm{C}$ for 30 seconds, anneling stage at $50^{\circ} \mathrm{C}$ for 30 seconds, extension stage at $72^{\circ} \mathrm{C}$ for 2 minutes, and post elongation at $72^{\circ} \mathrm{C}$ for 7 minutes. 


\subsubsection{Electrophoresis}

The amplification stage that has been completed is followed by the electrophoresis stage to read the molecular weight of the amplified DNA. In the electrophoresis stage, $2 \mathrm{~L}$ of the PCR test sample was mixed with $2 \mathrm{~L}$ of loading dye and then put into an agarose well. Agarose gel was made by using $1 \%$ agarose gel $(0.5 \mathrm{~g}$ agarose and $50 \mathrm{~mL}$ TAE Buffer $)$ with $4 \mathrm{~L}$ of ethidium bromide (EtBr) as a dye. The electrophoresis machine was set at $140 \mathrm{~V}$. The lawmass ladder was inserted into the agarose well to measure the length of the DNA base strand, and a UV transilluminator was used to visualize DNA bands on agarose gel media, the results of the UV transilluminator visualization were documented.

\subsubsection{Sequencing}

Sequencing was carried out with the aim of determining the sequence of nucleotide bases in DNA fragments that had been detected from visualization using a UV transilluminator that had previously been amplified using 16S rRNA sequences, sequencing was carried out using the Sanger method (1977). The PCR product sequencing process is sent to First Base, Malaysia. The data from the sequencing results were in the form of chromatograms which were then analyzed using bioinformatics software.

\subsection{Bioinformatic Analysis}

The molecular identification characteristics of the bacteria BLAST (Basic Local Alignment Search Tool) (https://blast.ncbi.nlm.nih.gov/Blast.cgi) was used to determine the suitability of target genes obtained with data from GeneBank NCBI (National Center for Biotechnology Information), and further verified by online analysis through the BOLD System (www.barcodinglife.org). The alignment process was carried out to analyze variations in the nucleotide base of the sample with its close relatives using Clustal X and BioEdit. Phylogenetic tree reconstruction was performed to determine the relationship between the sample and its relatives based on the composition of the nucleotide bases.

Phylogenetic trees construction was performed using the MEGA 6.0 (Molecular Evolutionary Genetic Analysis) computer program with the neighbor-joining tree (NJ) and maximum-likelihood (ML) methods with 1000 bootstraps. Algorithmic calculations used the Kimura-2 parameter model. Substitution of transitions and transversion of nucleotide bases was calculated by the Kimura-2 model.

Genetic distance is the value of the difference in genetic material between one species and another, the genetic distance value is used to determine the similarity value index by entering the formula in the Microsoft Excel application, with formula: (1-Genetic Distance Value) $* 100 \%$, the similarity value index makes it easy and as a reinforcement of the correctness of the value of genetic distance to determine the relationship between species.

\section{Results and Discussion}

The results of previous research were found that the characteristics of the bacterial form: round colony shape, flat colony edges, creamy white colony color, convex colony surface, and this colony were gram negative bacteria (Figure 2), then observed the shape of the bacteria using a microscope with a magnification of $100 \mathrm{x}$, the bacteria were diplococcus or round in pairs (Figure 3).

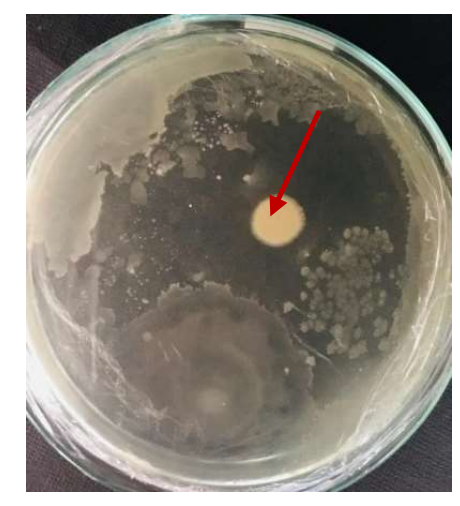

Fig 2. Bacterial pathogenic colony. Note: red arrow

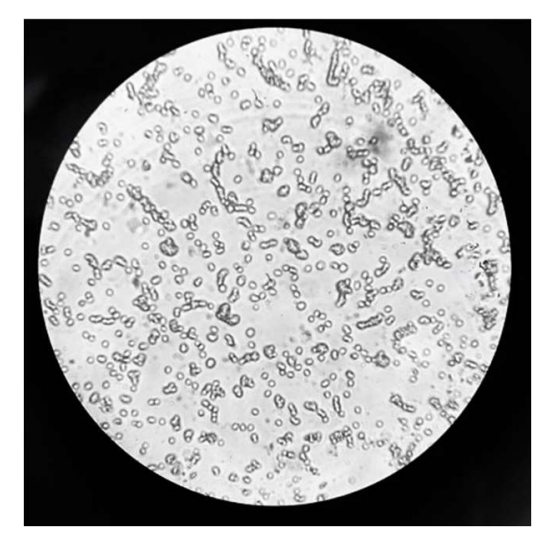

Fig 3. Diplococcus bacteria shape was observed with a microscope with a magnification of 100x.

In this study, we have adopted the universal primer introduced by [8]. The $16 \mathrm{~S}$ rRNA gene, a molecular marker for bacterial species identification, is ubiquitous among members of this domain and, thanks to ever-expanding sequence information databases, a useful tool for bacterial identification, while Clarridge [9] stated that 16S rRNA gene sequence analysis can improve the identification of poorly described, rarely isolated, or phenotypically aberrant strains, can be used routinely for mycobacteria identification, and can lead to the identification of novel pathogens and noncultured bacteria. Figure 4 shows the results of $16 \mathrm{~S}$ rRNA gene that was successfully amplified $\pm 700 \mathrm{bp}$. 


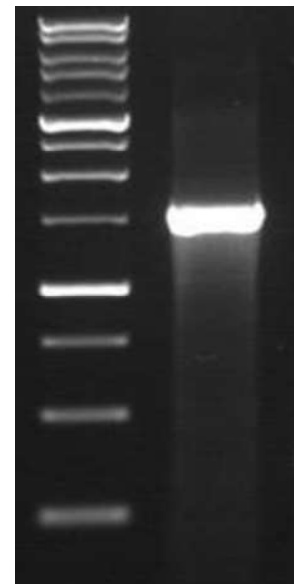

Fig. 4. Electrophoresis results of 16S rRNA gene Note: $\mathrm{M}=$ marker, $\mathrm{S}=$ Sample

Further alignment analysis was carried out to determine the homology level of the 16S rRNA gene sequence obtained between samples. The nucleotide base composition of the 16S rRNA gene showed that GC nucleotide base composition was greater than AT, GC nucleotide base composition was $55.89 \%$ while AT nucleotide base composition was $44.11 \%$. The nucleotide base variation of the 16S rRNA gene with 19 transition mutations was greater than the type of transversion mutation, which was 12 (Table 1). The composition of nucleotide bases with 16S rRNA sequences revealed that Adenine was 25.52 percent, Cytosine was 22.19 percent, Guanine was 33.70 percent, and Thymine was 18.59 percent.

The GC nucleotide base pair has a composition that is $55.89 \%$ greater than the AT nucleotide base pair. Guanine and cytosine base pairs dominated the nucleotide base composition of the 16S rRNA gene in the HR11082 bacterial isolate. The bond between guanine nucleotide bases and $\mathrm{G}-\mathrm{C}$ is strong because it has three hydrogen bonds, whereas the bond between A$\mathrm{T}$ nucleotide bases is weak because it only has two hydrogen bonds [9]; [4].

Table 1. Tipe mutasi, komposisi dan variasi basa nukleotida gen $16 \mathrm{~S}$ rRNA

\begin{tabular}{cccccc}
\hline Spesimen & $\boldsymbol{A}(\%)$ & $\boldsymbol{C}(\%)$ & $\boldsymbol{G}(\%)$ & $\begin{array}{c}\boldsymbol{T} \\
(\%)\end{array}$ & $\begin{array}{c}\boldsymbol{G C} \\
(\%)\end{array}$ \\
\hline HR11082 & 25,52 & 22,19 & 33,70 & $\begin{array}{c}18,5 \\
9\end{array}$ & $\begin{array}{c}55,89 \\
\%\end{array}$ \\
\hline Spesimen & $\boldsymbol{G C}(\%)$ & $\boldsymbol{A T}(\%)$ & $\boldsymbol{S i}$ & $\boldsymbol{S v}$ & \\
\hline HR11082 & $55,89 \%$ & $44,11 \%$ & 19 & 12 & \\
\hline
\end{tabular}

Note: $\mathrm{A}=$ Adenin $\mathrm{C}=$ Citosin; $\mathrm{G}=$ Guanin; $\mathrm{T}=$ Timin, $\mathrm{Si}=$ Mutasi Transisi, $\mathrm{Sv}=$ Mutasi Trasnsversi

Variations in nucleotide bases of bacterial isolate HR11082 with 16S rRNA sequences discovered more transition types than transversion types, which could be due to transversion having a higher chance of $1 / 140$, while transitions had a 1/58 chance between the four nucleotide bases. Transition bias can occur as a result of spontaneous mutations that result in larger transition mutations than transversion mutations, as well as mutations caused by natural selection, because transitional mutations are more synonymous than transversion mutations [10], [6]. Mutations in the sequence of nucleotide bases can occur by transition or transversion. When there is an exchange of purine bases or pyrimidine bases, it is called transition; when there is an exchange of purine bases with pyrimidine bases or vice versa, it is called transversion.

The pairwise-distance model was used to calculate the genetic distance between the study sample and its relatives, species from the genus Erwinia. The largest genetic distance between the sample and the bacterium Erwinia pyrifoliae was $0,48 \%$, while the smallest genetic distance was 0.17 percent with the bacterium Lelliottia nimiprssuralis (Table 5).

Genetic distance between samples in phylogenetic analysis based on 16S rRNA using kimura-2 parameter model. The lowest genetic distance of all samples was 0.000 and the highest genetic distance of all samples was 0.2004 . Genetic distance is the difference in nucleotide base variations between species or between populations in a particular species, the smaller the genetic distance indicates a close genetic relationship between species, whereas a large genetic distance indicates a distant genetic relationship between species [8]. A genetic distance value of less than $3 \%$ indicates the cluster or group is the same species, and a genetic distance of more than $3 \%$ indicates the cluster or group is a different species [11][12]. According to Priest \& Austin (1993), a microbe is declared a genus if it has a similarity index between $89 \%-99 \%$, and a species is declared if it has a similarity index of more than $97 \%$, and is declared a strain if it has a similarity index of $100 \%$. The bacterial isolate HR11082 has a close relationship with Lelliottia nimipressuralis with a genetic distance of 0.0173 and a similarity of $98.26 \%$, the genetic distance of the sample of bacterial isolate HR11082 with Erwinia aphidicola is 0.0247 with a similarity of $97.52 \%$, the data is in line with taxonomy that Lelliottia nimipressuralis with another name Erwinia nimipressuralis is a sub-species of Erwinia aphidicola, so it can be concluded that the HR11082 bacterial sample is of the same species as Lelliottia nimipressuralis and is also a close relative of Erwinia aphidicola.

Construction of phylogenetic topology between the sample of bacterial isolate HR11082 and close relatives of the genus Erwinia based on GeneBank and outgroups of the genus Xanthomonas were analyzed using the Neighbor-Joining Tree (NJ) and Maximum-Likelihood (ML) methods with the calculation of kimura-2 and boostrap parameters 100 times. A phylogenetic tree topology can be used to describe genealogical relationships between species or between populations in a diagram [10]. Based on the topology of the phylogenetic tree, the cladogram is divided into two clusters, the first cluster is an ingroup cluster of the genus Erwinia, and the second cluster is an outgroup of the genus Xanthomonas. Sequences with low boostrap values must be excluded from the analysis in order to obtain a reliable phylogenetic tree topology [13]. Sequences with higher boostrap values can increase the correctness of the results of topological reconstruction of phylogenetic trees [14]. If between species has a boostrap value of 100 , it can be concluded that the two 
isolates are very closely related and may be the same species [6]. The bacterial isolate HR11082 had a boostrap value of 99 with Erwinia aphidicola, and a boostrap value of 100 with Lelliottia nimipressuralis. The finding of this results showed that the bacterial isolate HR11082 was closely related to Erwinia aphidicola, and is the same species as Lelliottia nimipressuralis or with another name Erwinia nimipressuralis.

Table 2. Genetic distance based on 16S rRNA gene sequence using Kimura 2 Parameter calculation model (Percentage)

\begin{tabular}{|c|c|c|c|c|c|c|c|c|c|}
\hline No & Species & 1 & 2 & 3 & 4 & 5 & 6 & 7 & 8 \\
\hline 1. & AB680317.1 Erwinia amylovora & & & & & & & & \\
\hline 2. & $\begin{array}{l}\text { AM980502.1 Erwinia pyrifoliae } \\
\text { AM055716.1 Erwinia }\end{array}$ & 0,00143 & & & & & & & \\
\hline 3. & tasmaniensis & 0,01591 & 0,01738 & & & & & & \\
\hline 4. & HR11082 & 0,04726 & 0,04880 & 0,04273 & & & & & \\
\hline 5. & Y13249.1 Erwinia billingiae & 0,01736 & 0,01589 & 0,01593 & 0,04581 & & & & \\
\hline 6. & $\begin{array}{l}\text { AB273744.1 Erwinia aphidicola } \\
\text { MH788984.1 Lelliottia }\end{array}$ & 0,02470 & 0,02618 & 0,02029 & 0,02475 & 0,02622 & & & \\
\hline 7. & $\begin{array}{l}\text { nimipressuralis } \\
\text { AB558557.1 Xanthomonas }\end{array}$ & 0,02916 & 0,03066 & 0,02473 & 0,01736 & 0,02772 & 0,00719 & & \\
\hline 8. & $\begin{array}{l}\text { theicola } \\
\text { FR749910.1 Xanthomonas }\end{array}$ & 0,19711 & 0,19711 & 0,19500 & 0,21194 & 0,19500 & 0,20058 & 0,19489 & \\
\hline 9. & perforans & 0,19155 & 0,19155 & 0,18946 & 0,21961 & 0,19690 & 0,20047 & 0,20237 & 0,02328 \\
\hline
\end{tabular}
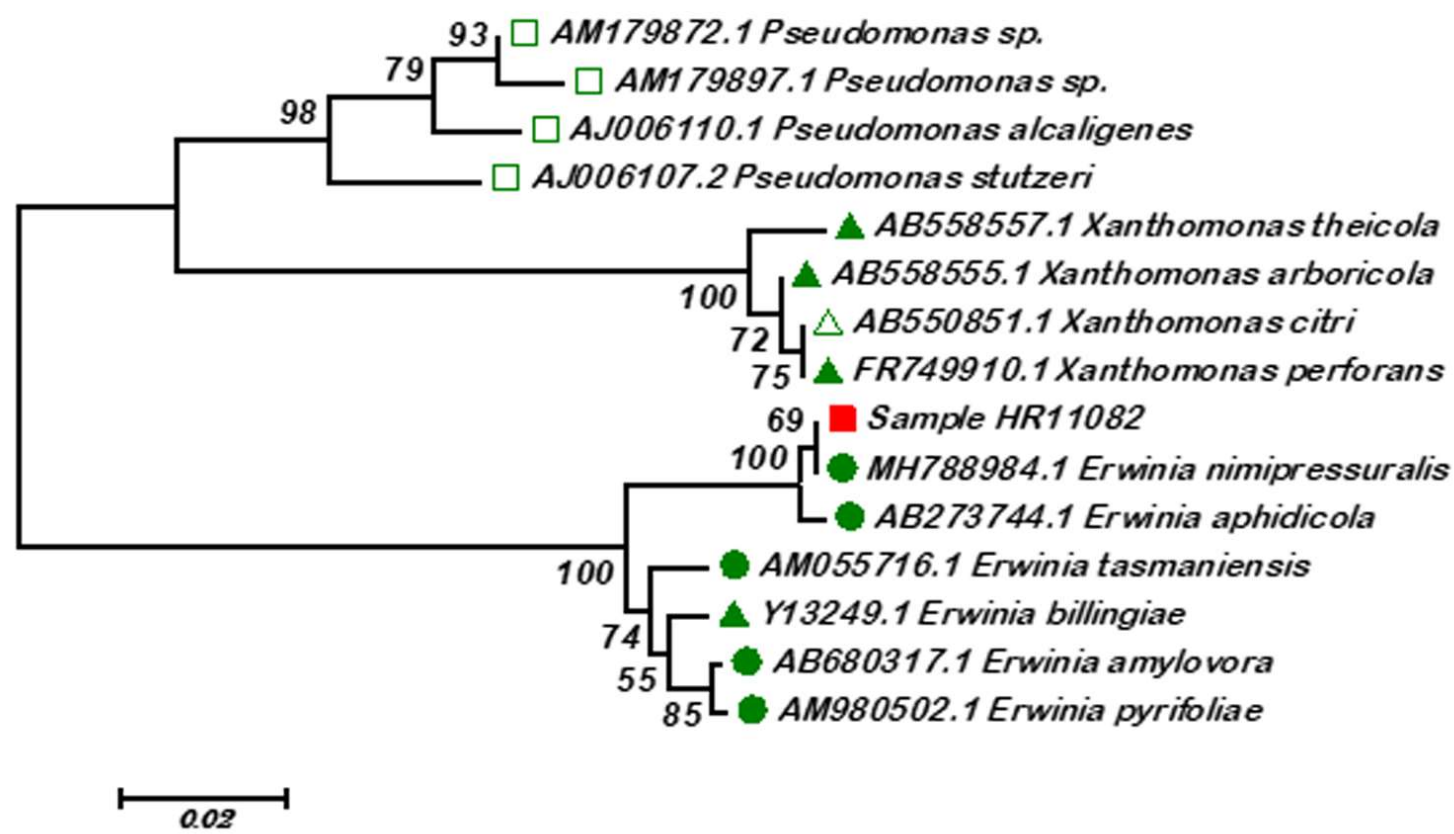

Fig 5. The phylogenetic topology of the research sample with the genus Erwinia and the genus Xanthomonas from the NCBI GeneBank used the Neighbor-Joining Tree (NJ) 


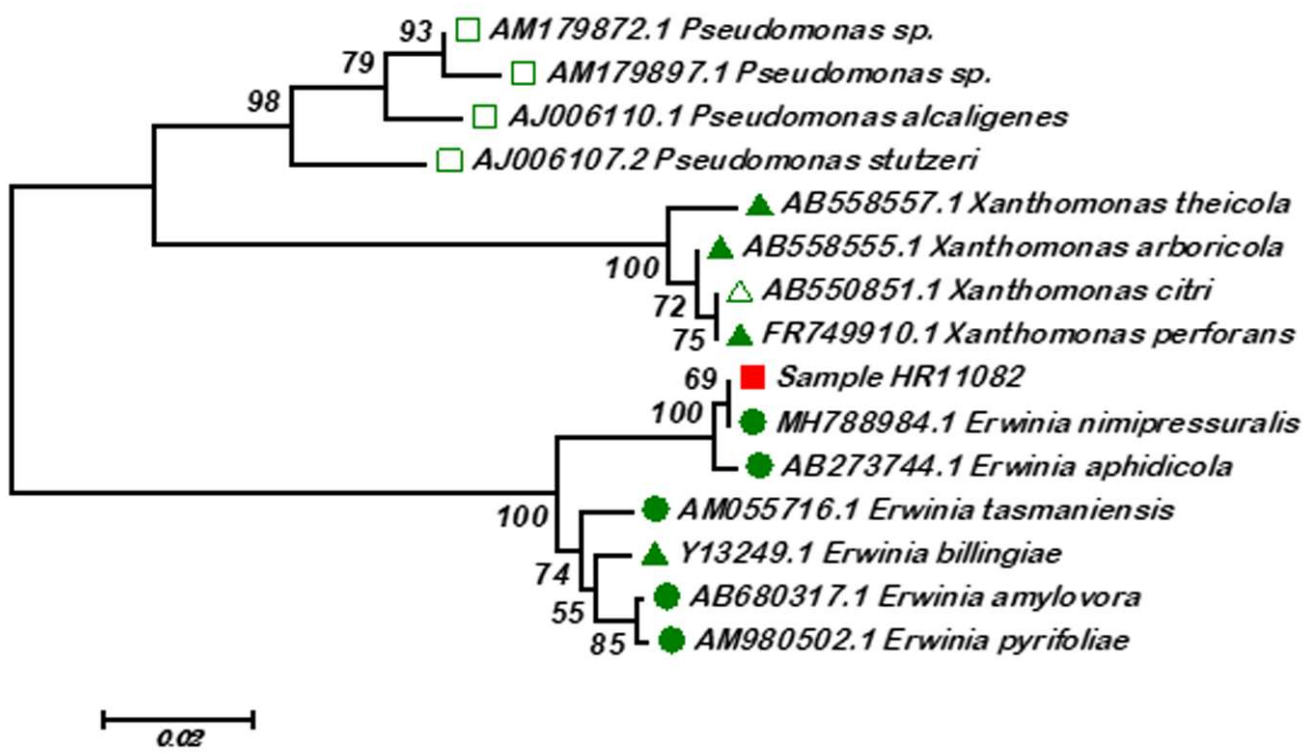

Fig 6. The phylogenetic topology of the research sample with the genus Erwinia and the genus Xanthomonas from the NCBI GeneBank used the Maximum Likelihood (ML)

\section{Conclusion}

The concluded of our research was the bacteria species attached in N. Gracillis identified as Lelliottia nimipressuralis, and closely related with Erwinia aphidicola. Thus, this study provides more information for Lelliottia nimipressuralis phylogenetic studies using different marker.

\section{References}

[1] L. Wang, Q. Zhou, Y. Zheng, and S. Xu, "Composite structure and properties of the pitcher surface of the carnivorous plant Nepenthes and its influence on the insect attachment system," Prog. Nat. Sci., vol. 19, no. 12, pp. 1657-1664, (2009), doi: 10.1016/j.pnsc.2009.09.005.

[2] M. Mansur, "LAJU PENYERAPAN CO2 PADA KANTONG SEMAR (Nepenthes gymnamphora Nees) DI TAMAN NASIONAL GUNUNG HALIMUN-SALAK, JAWA BARAT," J. Teknol. Lingkung., vol. 13, no. 1, p. 59, (2016), doi: 10.29122/jtl.v13i1.1405.

[3] Mardhiana, Y. Parto, R. Hayati, and D. P. Priadi, "Karakteristik dan Kemelimpahan Nepenthes di Habitat Miskin Unsur Hara," $J$. Lahan Suboptimal, vol. 1, no. 1, pp. 50-56, (2012).

[4] S. J. Bhore, V. Komathi, and K. I. Kandasamy, "Diversity of endophytic bacteria in medicinally important Nepenthes species," J. Nat. Sci. Biol. Med., vol. 4, no. 2, pp. 431-434, (2013, doi: 10.4103/0976-9668.117022.
[5] A. K. Fanani, A. L. Abadi, and L. Q. Aini, "EKSPLORASI BAKTERI PATOGEN PADA BEBERAPA SPESIES TANAMAN KANTONG SEMAR (Nepenthes sp.)," $J$. Hama dan Penyakit Tanam., vol. 3, no. 3, pp. 104-110, (2015).

[6] M. Drancourt, C. Bollet, A. Carlioz, R. Martelin, J. P. Gayral, and D. Raoult, "16S ribosomal DNA sequence analysis of a large collection of environmental and clinical unidentifiable bacterial isolates," J. Clin. Microbiol., vol. 38, no. 10, pp. 3623-3630, (2000), doi: $\quad 10.1128 / \mathrm{jcm} .38 .10 .3623-$ 3630.2000 .

[7] T. B. S. C. Bibiana Wid, "Identifikasi dan Keragaman Genetik Bakteri Asam Laktat dari Tapai Singkong berdasarkan Sekuen Gen 16S rRNA," J. Biota, vol. 2, no. 2, pp. 46-52, (2018), doi: 10.24002/biota.v2i2.1656.

[8] R. Srinivasan et al., "Use of 16S rRNA gene for identification of a broad range of clinically relevant bacterial pathogens," PLoS One, vol. 10, no. 2, pp. 1-22, (2015), doi: 10.1371/journal.pone.0117617.

[9] J. E. Clarridge, "Impact of 16S rRNA gene sequence analysis for identification of bacteria on clinical microbiology and infectious diseases," Clin. Microbiol. Rev., vol. 17, no. 4, pp. 840-862, (2004), doi: 10.1128/CMR.17.4.840-862.2004.

[10] T. Z. DeSantis et al., "Greengenes, a chimerachecked 16S rRNA gene database and workbench compatible with ARB," Appl. Environ. Microbiol., vol. 72, no. 7, pp. 5069- 
5072, (2006), doi: 10.1128/AEM.03006-05.

[11] Nurjanah, Zulhamsyah, and Kustiyariyah, "Kandungan mineral dan proksimat kerang darah (Anadara granosa) yang diambil dari Kabupaten Boalemo, Gorontalo," Bul. Teknol. Has. Perikan., vol. 8, no. 2, pp. 15-24, (2005), doi: https://doi.org/10.17844/jphpi.v8i2.1012.

[12] A. de Oliveira Ribeiro, R. A. Caires, T. C. Mariguela, L. H. G. Pereira, R. Hanner, and C. Oliveira, "DNA barcodes identify marine fishes of São Paulo State, Brazil," Mol. Ecol. Resour., vol. 12, no. 6, pp. 1012-1020, (2012), doi: 10.1111/1755-0998.12007.

[13] S. Meliah, A. W. Hardiyanti, N. Haida, G. A. Putri, and E. Q. Ainy, "Penapisan Bakteri Penghambat Fusarium yang Diisolasi dari Cairan Kantung Semar (Nepenthes sp.)," J. Ilmu Pertan. Indones., vol. 25, no. 4, pp. 627-635, (2020), doi: 10.18343/jipi.25.4.627.

[14] K. Tamura, G. Stecher, D. Peterson, A. Filipski, and S. Kumar, "MEGA6: Molecular evolutionary genetics analysis version 6.0," Mol. Biol. Evol., vol. 30, no. 12, pp. 2725-2729, (2013), doi: 10.1093/molbev/mst197. 